\title{
STUDI KASUS ASUHAN KEPERAWATAN PADA PASIEN HALUSINASI PENDENGARAN DI \\ RUANG KENANGA RUMAH SAKIT KHUSUS DAERAH PROVINSI SULAWESI SELATAN
}

The application of nursing care to patient auditory hallucinations in Kenanga room's at RSKD South Sulawesi Province

\author{
A.Nur Anna. $\mathbf{A} \mathbf{S}^{1}$ \\ Universitas Muhammadiyah Makassar \\ a.nur_anna@unismuh.ac.id
}

\begin{abstract}
Introduction hallucinations are mental disorders in which the client experiences sensory changes in perception, senses false sensations of vision, tasting touch or smell. The client feels a stimulus that actually does not exist. According to WHO (2018) the incidence of chronic and severe mental disorders that affect more than 21 million people and in general, there are more than 23 million people worldwide. research objectives the application of nursing care with cases of hallucinations, methods Case study, research results respondents know and practice how to overcome hallucinations, and conclusions improve the ability to control hallucinations.
\end{abstract}

Keywords : auditory hallucinations, implementation strategy, Schizophrenia.

\section{ABSTRAK}

Pendahuluan. Halusinasi adalah gangguan jiwa dimana klien mengalami perubahan sensori persepsi, merasakan sensasi palsu penglihatan, pengecapan perabaan atau penghiduan. Klien merasakan stimulus yang sebetulnya tidak ada. Menurut WHO (2018) Angka kejadian gangguan mental kronis dan parah yang menyerang lebih dari 21 juta jiwa dan secara umum terdapat lebih dari 23 juta orang jiwa diseluruh dunia.Tujuan, penulis dapat mengembangkan pengetahuan dalam penerapan asuhan keperawatan dengan kasus halusinasi. Metode: studi kasus. Hasil: responden mengetahui dan mempraktekkan cara mengatasi halusinasi. Kesimpulan: Meningkatkan kemampuan mengontrol halusinasinya.

Kata kunci : Halusinasi pendengaran, starategi implementasi, skizoprenia

\section{PENDAHULUAN}

Kesehatan jiwa menurut Undang-Undang Republik Indonesia No 18 Tahun 2014 adalah kondisi di mana seorang individu dapat berkembang secara fisik, mental, spiritual, dan sosial sehingga individu tersebut menyadari kemampuan sendiri, dapat mengatasi tekanan, dapat bekerja secara produktif, dan mampu memberikan kontribusi untuk komunitasnya. Kesehatan jiwa adalah keadaan sejahtera yang ditandai dengan perasaan bahagia, keseimbangan, merasa puas, pencapaian diri dan harapan (Stuart, Keliat \& Pasaribu, 2016).

Menurut Diagnostic Statistic Mental (DSM) IV gangguan jiwa adalah pola perilaku individu yang menyebabkan disfungsi dan penderitaan sehingga terjadi kerugian dan konflik di masyarakat. Menurut Pedoman Penggolongan Diagnosis Gangguan Jiwa (PPDGJ) III bahwa gangguan jiwa adalah pola perilaku yang menyebabkan terjadinya penderitaan dan keterbatasan (Maslim, 2013).

Berdasarkan pengertian gangguan jiwa di atas disimpulkan bahwa gangguan jiwa adalah suatu keadaan individu yang tidak normal atau terjadi gangguan pada fungsi jiwa di mana individu mengalami perubahan pola perilaku dan emosional sehingga menyebabkan penderita mengalami hambatan dalam peran sosial, terjadi kerugian dan konflik di masyarakat serta penderita mengalami keterbatasan. Jika tidak segera ditangani dengan baik maka pasien yang mengalami gangguan jiwa akan menderita semakin parah menjadi gangguan jiwa berat (Skizofrenia) dan berakibat buruk baik bagi klien sendiri, keluarga, masyarakat maupun lingkungannya.

Menurut WHO (2018) Angka kejadian gangguan mental kronis dan parah yang menyerang lebih dari 21 juta jiwa dan secara umum terdapat lebih dari 23 juta orang jiwa di seluruh dunia, Jasa lebih dari $50 \%$ orang dengan skizofrenia tidak menerima perawatan yang tepat. $90 \%$ orang dengan skizofrenia yang tidak diobati tinggal di Negara berpenghasilan rendah dan menengah. Berdasarkan Riskesdas (2018), prevalensi gangguan jiwa di Indonesia pada tahun 2013 sebanyak 1,7 per mil dan mengalami peningkatan pada tahun 2018 menjadi 7 per mil.

Halusinasi adalah salah satu gejala gangguan persepsi sensori yang dialami oleh pasien gangguan jiwa (Keliat, Akemat, Helena, \& 
Nurhaeni, 2013). Halusinasi adalah distorsi persepsi palsu yang terjadi pada respon neurobiologis maladaptif. Klien sebenarnya mengalami distorsi sensori sebagai hal yang nyata dan meresponnya (Stuart, Keliat \& Pasaribu, 2016). Halusinasi adalah salah satu gejala gangguan jiwa di mana klien mengalami perubahan sensori persepsi, merasakan sensasi palsu berupa suara, penglihatan, pengecapan, perabaan atau penghiduan. Klien merasakan stimulus yang sebetul-betulnya tidak ada (Damaiyanti \& Iskandar, 2012).

Diperkirakan lebih dari $90 \%$ klien skizofrenia mengalami halusinasi. Meskipun bentuk halusinasinya bervariasi tetapi sebagian besar pasien skizofrenia mengalami halusinasi pendengaran. Suara itu dapat berasal dari dalam diri individu atau dari luar individu. Suara yang didengar pasien dapat dikenalnya, suara dapat tunggal atau multiple atau bisa juga mengandung arti. Isi suara dapat memerintahkan tentang perilaku pasien sendiri, pasien sendiri merasa yakin bahwa suara itu berasal ada (Yosep \& Sutini, 2016).

Berdasarkan hasil penelitian Suryani (2013) di RSJ Cimahi dengan judul Proses terjadinya halusinasi: sebagaimana diungkapkan oleh penderita Skizofrenia dengan pendekatan Collaizi diketahui bahwa terdapat lima proses individu mengalami halusinasi, yaitu: adanya serangkaian masalah yang dipikirkan, adanya situasi/kondisi sebagai pencetus, terjadi secara bertahap, membutuhkan waktu lama sebelum terjadi halusinasi, adanya tema pendekatan spiritual dan penggunaan koping yang konstruktif sebagai upaya pencegahan halusinasi baik secara individu maupun support dari keluarga.

Melihat tingginya angka gangguan jiwa yang mengalami halusinasi merupakan masalah serius dan memprihatinkan bagi dunia kesehatan dan keperawatan khususnya di Indonesia. Pada penderita halusinasi jika tidak ditangani dengan baik akan berakibat buruk bagi klien sendiri, keluarga, orang lain dan lingkungan. Tidak jarang ditemukan pada penderita gangguan jiwa yang melakukan tindak kekerasan karena halusinasi. Oleh karena itu kita sebagai tenaga kesehatan yang nantinya memberikan asuhan keperawatan yang profesional diharapkan mampu mengatasi hal ini dan bisa meningkatkan pelayanan terhadap masyarakat sehingga Indonesia menjadi negara yang sehat jiwanya.

Berdasarkan informasi dan data yang telah diuraikan di atas, penulis merasa tertarik untuk melaksanakan studi kasus yang berjudul "Penerapan Asuhan Keperawatan pada pasien Halusinasi Pendengaran di ruang kenari rumah sakit khusus daerah provinsi sulawesi selatan".

Penulis dapat mengembangkan pengetahuan di dalam penerapan asuhan keperawatan pada pasien halusinasi pendengaran di ruang kenari rumah sakit khusus daerah provinsi sulawesi selatan tahun.

\section{METODE \\ Desain, tempat dan waktu}

Studi kasus ini menggunakan penelitian dengan menggunakan pendekatan deskriptif. Pendekatan deskriptif adalah melakukan analisis hanya sampai taraf deskripsi, yaitu menganalisis dan menyajikan fakta secara sistematik sehingga dapat lebih mudah untuk dipahami dan di simpulkan (Siswanto, Susila, \& Suyanto 2015). Tempat pelaksanaan di Rumah Sakit Khusus Daerah Dadi Provinsi Sulawesi selatan. Pada 29 Mei s/d 10 Juni 2019.

\section{Jumlah dan cara pengambilan subjek (untuk penelitian survei) atau}

Populasi pada penelitian ini adalah 15 orang, dan memenuhi kriteria inklusi sebanyak 3 orang untuk menjadi responden. Metode yang digunakan adalah studi kasus dalam penerapan pemberian asuhan keperawatan pada pasien halusinasi pendengaran

HASIL

Berdasarkan dari hasil wawancara responden mengatakan sering mendengarkan suara-suara. Kondisi pasien saat ini, sering berhalusinasi. Data Subjektif, Pasien mengatakan sering mendengar bisikan setan, pasien mengatakan sering mendengar suara kuntilanak yang sedang tertawa, pasien mengatakan sering mendengar suara genderuwo yang memerintahkan untuk pergi dari rumah, pasien mengatakan jika bisikan itu datang pasien gelisah, ketakutan, pasien mengatakan halusinasi muncul pada siang hari dan malam hari, dan yang paling sering muncul pada malam hari pada saat melamun dan berbaring, pasien mengatakan halusinasi muncul kurang lebih 2 menit. Pasien mengatakan punya banyak masalah yang tidak bisa diatasi, pasien mengatakan sering melamun, Sering melamun, sering mondar-mandir, mengamuk di rumah, pasien mengatakan sering mendengar suara setan di telinga kiri dan telinga kanan, pasien mengatakan sering mendengar orang yang menyuruhnya mencuri uang, pasien nampak mondar-mandir dan nampak gelisah, pasien nampak ketakutan. mengatakan sering mendengar suara laki-laki yang memerintahkan untuk memukul adiknya. Data objektif pasien nampak selalu melamun, pasien nampak gelisah, pasien nampak sedih, pasien nampak hanya duduk di tempat tidur dan sudut ruangan, pasien nampak jarang berkomunikasi, kontak mata kurang.

Status kesehatan mental: Penampilan: pasien berpenampilan sesuai dengan umurnya tapi pakaian pasien tampak kotor, dandanan pasien 
sesuai, kontak mata kurang. Pembicaraan: berbicara dengan nada suara yang lembut, cara bicara cepat dan lambat. Aktivitas motorik: pasien nampak gelisah. Alam perasaan: sedih dengan keadaannya sekarang. Afek: pasien mengalami afek labil (mudah berubah-ubah kadang emosi, kadang senyum-senyum sendiri dan kadang diam) saat berinteraksi dengan pasien mimik muka pasien berubah-ubah, saat berbicara yang menyenangkan mimik muka pasien tersenyum, saat berbicara yang menyedihkan mimik muka pasien sedih dan terlihat diam bahkan mengeluarkan suara yang keras. Interaksi selama wawancara: saat berbicara pasien nampak curiga menoleh ke kiri dan ke kanan, serta mudah beralih. Persepsi: pasien mengalami halusinasi pendengaran pasien mengatakan mendengar sering suara setan di telinga kiri dan telinga kanan, pasien mengatakan sering mendengar orang yang menyuruhnya mencuri uang, pasien mengatakan saat suara itu datang pasien memukul adiknya, Pasien mengatakan sering mendengar bisikan setan, pasien mengatakan sering mendengar suara kuntilanak yang sedang tertawa, pasien mengatakan sering mendengar suara genderuwo yang memerintahkan untuk pergi dari rumah, pasien mengatakan halusinasinya pada saat menyendiri atau melamun, pasien mengatakan halusinasinya muncul pada pagi, siang, malam hari, biasa halusinasinya muncul tiba-tiba dan frekuensinya itu tidak lama kurang lebih 2 menit. Proses pikir: Sirkumtansial: pembicaraannya pasien berbelit-belit tapi masih bisa dimengerti. Tingkat kesadaran: pasien nampak bingung dan tidak mengalami disorientasi waktu dan tempat. Memori: (gangguan daya ingat jangka panjang) pasien masih mengingat perawatnya. Tingkat konsetrasi dan berhitung: (mudah beralih) perhatian pasien mudah berganti-ganti. Kemampuan penilaian: pasien dapat mengambil keputusan. Daya tilik diri: meyalahkan hal-hal di luar dirinya.

Intervensi dan implementasi yang dibuat berdasarkan diagnosa keperawatan antara lain, SP1P terdiri dari yaitu mengidentifikasi jenis halusinasi pasien, mengidentifikasi isi halusinasi pasien, mengidentifikasi waktu halusinasi pasien, mengidentifikasi frekuensi halusinasi pasien, mengidentifikasi situasi yang menimbulkan halusinasi pasien, mengidentifikasi respon pasien terhadap halusinasi, mengajarkan pasien menghardik halusinasi, dan menganjurkan pasien memasukkan cara menghardik halusinasi dalam kegiatan harian. SP2P terdiri dari yaitu mengevaluasi jadwal kegiatan harian pasien, melatih pasien mengendalikan halusinasi dengan cara bercakapcakap dengan orang lain, dan menganjurkan pasien memasukkan ke dalam jadwal kegiatan harian. SP3P terdiri dari yaitu mengevaluasi jadwal kegiatan harian pasien, melatih pasien mengendalikan halusinasi dengan cara melakukan kegiatan (kegiatan yang biasa dilakukan di rumah), dan menganjurkan pasien memasukkan ke dalam jadwal kegiatan harian. SP4P terdiri dari yaitu mengevaluasi jadwal kegiatan harian pasien, memberikan pendidikan kesehatan tentang penggunaan obat secara teratur, dan menganjurkan pasien memasukkan ke dalam jadwal kegiatan harian.

Evaluasi: mengatakan masih mendengar suara bisikan, pasien mengatakan mondar-mandir saat mendengar suara kuntilanak yang sedang tertawa dan suara genderuwo yang menyuruhnya untuk pergi, pasien mengatakan halusinasi muncul saat melamun, lamanya muncul sekitar kurang lebih 2 menit. Data Objektif yang didapatkan yaitu pasien Nampak melamun dan tegang, pasien dapat mempraktekkan cara menghardik halusinasi. mengatakan masih mendengar suara bisikan lakilaki yang memerintahkan untuk memukul adiknya. Data Objektif didapatkan pasien duduk menyendiri di sudut ruangan. Hasil yang didapatkan peneliti yaitu, pasien mampu menghardik halusinasi. pasien mengatakan masih sering mendengar suarasuara ketika sedang sendiri. Data objektif, pasien nampak curiga menoleh ke kiri dan ke kanan, pasien tampak kooperatif, pasien mengatakan sudah tau cara menghardik. Hasil yang dapatkan peneliti pasien mampu mempraktekkan cara menghardik halusinasi yaitu bercakap-cakap dengan orang lain.

Pasien mengatakan masih sering mendengar suara-suara orang menyuruhnya mencuri uang, pasien mau bercakap- cakap dengan orang lain. Data objektif, pasien nampak kooperatif, kontak mata ada, pasien mengatakan sudah tau cara menghardik halusinasi. Hasil yang dapatkan peneliti pasien mampu mempraktekkan cara menghardik halusinasi yaitu. melakukan kegiatan yang biasa dilakukan di rumah. mengatakan masih mendengar suara kuntilanak yang sedang tertawa, pasien mengatakan gelisah mendengar suara kuntilanak itu, data objektif pasien nampak ketakutan dan gelisah. Dan mengatakan mendengar suara laki-laki yang menyuruh dia memukul adiknya. Hasil yang didapatkan peneliti yaitu pasien mampu menghardik halusinasi dengan cara meminum obat secara teratur. pasien dengan data subjektif, pasien mengatakan masih sering mendengar suara-suara orang menyuruhnya mencuri uang dan pasien mengatakan masih sering mendengar suara setan. Data objektif, pasien nampak kooperatif, kontak mata ada, pasien mengatakan sudah tau cara menghardik halusinasi. Hasil yang dapatkan peneliti pasien mampu mempraktekkan cara menghardik halusinasi yaitu minum obat secara teratur. mengatakan masih mendengar suara suara bisikan. Pasien mampu mempraktekkan menghardik halusinasi dengan cara 
bercakap-cakap dengan orang lain. Pasien Mengatakan masih mendengar suara bisikan. Pasien mengatakan sudah tau cara menghardik halusinasi. Hasil yang didapatkan peneliti yaitu pasien mampu melakukan aktivitas seperti kebiasaan yang dilakukan dirumah.

\section{PEMBAHASAN}

Berdasarkan penelitian Suryani (2013), mengungkapkan bahwa terjadinya halusinasi berhubungan erat dengan beratnya masalah yang dipersepsikan oleh individu dan koping yang dimilikinya untuk mengatasi masalahnya. Selain itu kejadian halusinasi berikutnya dicetuskan oleh kejadian-kejadian tertentu dalam kehidupan individu yang biasanya mengganggu perasaan dan pikirannya.Sedangkan menurut Yosep dan Sutini (2016), mengatakan bahwa gangguan jiwa persepsi sensori dengan gangguan psikotik erat sekali penyebabnya dengan faktor genetik termasuk di dalamnya saudara kembar atau anak adopsi. Terdapat tanda dan gejala senyum sendiri, ketawa sendiri, sikap curiga, tidak dapat mengurus diri, menggerakkan bibir tanpa suara (Hamid (2000) dalam buku Damaiyanti dan Iskandar (2012)

Berdasarkan penelitian Jalil (2012), bahwa sebagian besar pasien yang mengalami halusinasi yang mengganggu dan muncul pada saat malam hari. Sedangkan menurut Yosep dan Sutini (2016), individu yang mengalami halusinasi sering kali beranggapan penyebab halusinasi berasal dari lingkungannya, padahal rangsangan halusinasi timbul setelah adanya hubungan yang bermusuhan, tekanan, isolasi, perasaan tidak berguna, putus asa, dan tidak berdaya.

Menurut Cancro dan Lehman (2000) dalam buku Videbeck (2008), pasien yang mengalami halusinasi pendengaran akan mengalami gejala seperti mendengarkan suara-suara, paling sering adalah suara berbicara kepada pasien atau membicarakan pasien. Mungkin ada satu atau banyak suara yang dapat berupa suara yang dikenal atau suara tidak dikenal.

Berdasarkan buku Damaiyanti dan Iskandar (2012), intervensi keperawatan halusinasi atau strategi pelaksanaan yaitu SP1P terdiri dari yaitu mengidentifikasi jenis, isi, waktu dan frekuensi halusinasi pasien, serta mengidentifikasi situasi yang menimbulkan halusinasi pasien, mengidentifikasi respon pasien terhadap halusinasi, mengajarkan pasien menghardik halusinasi, dan menganjurkan pasien memasukkan cara menghardik halusinasi dalam kegiatan harian. SP2P terdiri dari yaitu mengevaluasi jadwal kegiatan harian pasien, melatih pasien mengendalikan halusinasi dengan cara bercakap-cakap dengan orang lain, dan menganjurkan pasien memasukkan ke dalam jadwal kegiatan harian. SP3P terdiri dari yaitu mengevaluasi jadwal kegiatan harian pasien, melatih pasien mengendalikan halusinasi dengan cara melakukan kegiatan (kegiatan yang biasa dilakukan di rumah), dan menganjurkan pasien memasukkan ke dalam jadwal kegiatan harian. SP4P terdiri dari yaitu mengevaluasi jadwal kegiatan harian pasien, memberikan pendidikan kesehatan tentang penggunaan obat secara teratur, dan menganjurkan pasien memasukkan ke dalam jadwal kegiatan harian.

Berdasarkan penelitian Sustrami dan Sundari (2014), menyatakan bahwa terdapat perbedaan kemampuan pasien dalam mengontrol halusinasi sebelum dan sesudah dilakukan Terapi Aktivitas Kelompok stimulasi persepsi halusinasi. Kemampuan pasien dalam mengontrol halusinasi setelah dilakukan Terapi Aktivitas Kelompok stimulasi persepsi halusinasi semuanya mampu mengenal dan menghardik halusinasi dibandingkan dengan pasien yang belum dilakukan Terapi Aktivitas Kelompok sebagian besar yang tidak mampu mengenal dan menghardik halusinasi.

Berdasarkan hasil penelitian dari Wahyuni, Keliat, Yusron dan Susanti (2011), menunjukkan bahwa halusinasi menurun secara bermakna pada kelompok yang mendapat cognitive behavior therapy sedangkan pada kelompok yang tidak mendapat cognitive behavior therapy menurun secara tidak bermakna. Sedangkan berdasarkan hasil penelitian Twistiandayani dan Widati (2013), menyatakan bahwa terapi tought stopping memberikan pengaruh bermakna terhadap halusinasi kemampuan mengontrol halusinasi pada pasien skizofrenia. Selain penelitian di atas Usman dan Retiani (2015), mengungkapkan bahwa kemampuan mengontrol halusinasi pasien skizofrenia sebelum melaksanakan teknik mengontrol halusinasi sebagaian besar dalam klasifikasi kurang. Sedangkan kemampuan mengontrol halusinasi pasien skizofrenia setelah melaksanakan teknik mengontrol halusinasi sebagian besar dalam klasifikasi cukup dan baik.

\section{KESIMPULAN}

Berdasarkan hasil studi kasus ditemukan data bahwa pasien halusinasi pendengaran berbeda-beda isi halusinasinya, waktu dan frekuensi. Intervensi yang diberikan membantu pasien mengenal halusinasinya, mengajarkan pasien mengontrol halusinasi dengan cara menghardik, mengajarkan pasien mengontrol halusinasi dengan cara bercakap-cakap dengan orang lain, mengajarkan pasien mengontrol halusinasi dengan cara melakukan kegiatan yang biasa dilakukan di rumah, dan mengajarkan pasien mengontrol halusinasi dengan cara memberikan pendidikan kesehatan tentang penggunaan obat secara teratur. 


\section{SARAN}

Diharapkan perawat mampu memberikan terapi spesialis untuk membantu responden meningkatkan kemampuannya.

\section{UCAPAN TERIMA KASIH}

Ibu Ratna Mahmud selaku Ka. Prodi DIII
Keperawatan Fakultas Kedokteran Dan IImu Kesehatan Unversitas Muhammadiyah Makassar yang telah memberikan motivasi dalam menyelesaikan Karya Tulis IImiah ini. Direktur Rumah Sakit Khusus Daerah Dadi Provinsi Sulawesi selatan dan Mahasiswa yang telah membantu.

\section{DAFTAR PUSTAKA}

Damaiyanti, M., \& Iskandar. (2012). Asuhan Keperawatan Jiwa. Bandung: Refika Aditama.

Jalil, A. (2012). Pengaruh Presipitasi, Waktu Dan Respon Halusinasi Terhadap Durasi Halusinasi Pasien Skizofrenia Di RSJ Prof. Dr. Soerojo Magelang. Jurnal Kesehatan, 1(1) 1-12. Diakses dari: https://www.scribd.com/doc/243942481/jurnal-halusinasi-pdf

Keliat, B, A., Akemat, Helena, N. \& Nurhaeni, H. (2013). Keperawatan Kesehatan Jiwa Komunitas. Jakarta: EGC.

Maslim, R. (2013). Diagnosis gangguan jiwa: Rujukan ringkas dari PPDGJ III dan DSM IV. Jakarta: PT. Nuh Jaya.

Riset Kesehatan Dasar, Riskesdas. (2018). Report of the Riskesdas. Diakses dari: http://www.depkes.go.id/resources/download/general/Hasil\%20Riskesdas\%2201.pdf

Siswanto, Susila., \& Suryanto (2015). Metodologi Penelitian Kesehatan dan Kedokteran. Yogyakarta: Bursa IImu.

Stuart, G, W., Keliat, B, A., \& Pasaribu, J. (2016). Prinsip Dan Praktik Keperawatan Kesehatan Jiwa Stuart. Singapore: Elsevier.

Suryani (2013). Pengalaman Penderita Skizofrenia Tentang Proses Terjadinya Halusinasi. Ilmu Kesehatan Jp Keperawatan dd. Diakses dari: http://www.ejurnal.com/2016/11/pengalamanpenderita-skizofrenia.html

Suryani (2013). Pengalaman Penderita Skizofrenia Tentang Proses Terjadinya Halusinasi. 1(1). Diakses dari: http://jkp.fkep.unpad.ac.id/index.php/jkp/article/download/46/43

Sustrami, D., \& Sundari, S. (2014). Efektivitas Pelaksanaan Terapi Aktivitas Kelompok Stimulasi Persepsi Halusinasi Terhadap Kemampuan Pasien Skizofrenia Dalam Mengontrol Halusinasi Di Ruang Flamboyan Rumah Sakit Jiwa Menur Surabaya. Jurnal Kesehatan, 6(2), 86-93. Diakses dari: https://adysetiadi.files.wordpress.com/2012/03/jurnal-aiptinakes-vol-6-no-2-sept-2014.pdf

Twistiandayani, R., \& Widati, A. (2013). Pengaruh Terapi Tought Stopping Terhadap Kemampuan Mengontrol Halusinasi Pada Pasien Skizofrenia. Prosiding Konferensi Nasional PPNI Jawa Tengah. 240-242. Diakses dari: http://download. portalgaruda.org/article.php?article=98548\&val=426

Undang-undang Republik Indonesia Nomor 182014 tentang kesehatan jiwa. Diakses dari: http://binfar.kemkes.go.id/?wpdmact=process\&did=MjAxLmhvdGxpbms

Usman, \& Retiana. (2015). Pelaksanaan Teknik Mengontrol Halusinasi: Kemampuan Klien Skizofrenia Mengontrol Halusinasi. The Sun, 2(1) 68-73. diakses dari: http://docplayer.info/38014948-Pelaksanaan-teknikmengontrol-halusinasi-kemampuan-klien-skizofrenia-mengontrol- halusinasi.html

Videbeck, S. (2008). Buku Ajar Keperawatan Jiwa (Psychiatric Mental Health Nursing). Jakarta: EGC.

Wahyuni, S, E., Keliat, B. A. Yusron, \& Susanti, H. (2011) Penurunan Halusinasi Pada Klien Jiwa Melalui Cognitive Behavior Theraphy. Jurnal Keperawatan Indonesia, 14(3), 185-192. Diakses dari: 
Jurnal Media Keperawatan: Politeknik Kesehatan Makassar

Vol. 10 No.02 2019

e-issn : 2622-0148, p-issn : 2087-0035

http://jki.ui.ac.id/index.php/jki/article/download/66/66

World Health Organization Schizophrenia. (2017). Report of the WHO Schizophrenia. Diakses dari: http://www.who.int/mediacentre/factsheets/fs396/en/

Yosep, I,. \& Sutini, T. (2016). Buku Ajar Keperawatan Jiwa dan Advance Mental Health Nursing. Bandung: Refika Aditama. 